W książce znaleźć można bardzo wiele przypisów opisowych, które uzupełniają główny wywód Autora i świadczą o jego erudycji. W niektórych przypadkach przypisy zajmują prawie cała stronę (na przykład, s. 188-189), co przy małej czcionce znacznie utrudnia lekturę. Niemniej, zarówno imponująca liczba, jak i jakość wykorzystanych materiałów źródłowych, zasługują na najwyższe uznanie. Wystarczy wspomnieć, że w toku prac nad książką Radosław Fiedler skorzystał z setek dokumentów, monografii oraz artykulów. Większość z nich stanowią publikacje w języku angielskim, co wiązało się z koniecznością thumaczeń i interpretacji materiałów. Bibliografia obejmuje aż 39 stron. Całość uzupełniają 42 tabele, osiem schematów oraz aneks, zawierający pięć map.

Podsumowując, z całą pewnością najnowsza publikacja autorstwa Radosława Fiedlera jest pozycją wartą polecenia wszystkim zainteresowanym nie tylko sytuacją polityczną na Bliskim Wschodzie czy też polityką zagraniczną Stanów Zjednoczonych, ale też wszystkim czytelnikom, którym bliskie są współczesne stosunki międzynarodowe. Książka stanowi cenny wkład w rozwój polskiej literatury przedmiotu oraz jest przykładem, świeżego spojrzenia" na bieżące wydarzenia w regionie. W przeciwieństwie do książek wielu autorów amerykańskich, monografia Radosława Fiedlera nie zdradza zaangażowania po którejś ze stron amerykańskiej sceny politycznej i stanowi udaną próbę bezstronnej oceny polityki zagranicznej USA w odniesieniu do Bliskiego Wschodu. Jej mocnymi stronami sa przede wszystkim rzetelne opracowanie, solidna podstawa źródłowa, oryginalność spostrzeżeń oraz aktualność.

Przemysław OSIEWICZ Uniwersytet im. Adama Mickiewicza, Poznań

\title{
Joanna Dobrowolska-Polak, Ludzie w cieniu wojny. Ludność cywilna podczas wspótczesnych konfliktów zbrojnych, Poznań 2011, ss. 224
}

Monografia Ludzie w cieniu wojny podejmuje temat rzadko rozpatrywany w polskiej literaturze naukowej-sytuację ludności cywilnej na obszarach konfliktów zbrojnych. Analizuje ona także normy prawa międzynarodowego określające należny sposób traktowania ludności cywilnej oraz ocenia stopień ich implementacji.

Ludność cywilna stanowi obecnie około 90 procent wszystkich śmiertelnych ofiar wojen czy konfliktów zbrojnych. Ze względu na charakter współczesnych konfliktów odsetek cywilów wśród ogółu ofiar cały czas wzrasta. Dla przykładu podczas pierwszej wojny światowej wynosil on 5, a w trakcie drugiej wojny światowej już 50 procent. Stąd też konieczność dokonania analizy nie tylko współczesnych wojen czy konfliktów, ale także ukazania zakresu ochrony przysługującej ludności cywilnej. Bezpośrednio i pośrednio nawiąuje do tego pierwsza część książki. Został w niej przedstawiony również proces ,humanitaryzacji wojny", który doprowadził do powstania koncepcji ,,minimalnego standardu humanitarnego" czy też - przyjmując terminologię ONZ - ,fundamentalnego standardu ludzkości", określającego katalog norm obowiązujących w każdej sytuacji, niezależnie od charakteru i rodzaju konfliktu zbrojnego. Autorka szczególowo omawia też następujące kwestie: zasady prawa wojennego, rozwój praw człowieka i prawa humanitarnego, ochronę m.in. dzieci, 
kobiet czy uchodźców oraz ideę i zasady funkcjonowania tzw. stref bezpiecznych, czyli obszarów wolnych od działań zbrojnych.

Stosowany tutaj wywód jest logiczny i wewnętrznie spójny, choć niektóre kwestie (jak np. źródła obu systemów prawnych) mogłyby zostać omówione szerzej. Z kolei wielkim atrybutem tej części książki jest analiza norm dotyczących ochrony ludności. Szkoda jednak, że Autorka zrezygnowała z pogłębionej analizy rezolucji i raportów ONZ dotyczących powyższych kwestii.

Istotą drugiej części książki jest rozpatrzenie poszanowania prawa humanitarnego i praw człowieka podczas konfliktów zbrojnych, w tym traktowania ludności cywilnej w obliczu dokonywanych na masową skalę zbrodni. Autorka klasyfikuje ponadto rodzaje ataków na ludność cywilna, charakteryzując kolejno: ataki na życie człowieka, godność i nietykalność, wolność i bezpieczeństwo, łamanie humanitarnych zasad prowadzenia konfliktów zbrojnych oraz ludobójstwo i politykę czystek etnicznych. Jaskrawo uwidacznia skalę naruszeń praw: kobiet (m.in. opisuje i grupuje ataki na tle seksualnym), dzieci (przedstawia przymusową rekrutację do sił zbrojnych i grup paramilitarnych), uchodźców oraz mężczyzn objętych rekrutacją do sił zbrojnych.

Ostatnia część monografii to analiza studiów przypadku (,kumulacja aktów przemocy") podczas konfliktów w: Kosowie, Czeczenii, Rwandzie, Afganistanie i sudańskim Darfurze. $Z$ zachowaniem naukowego obiektywizmu Autorka przedstawia swoje, czasami bardziej osobiste, oceny. Przejawem tego jest choćby bezpośrednie nawiązanie do słów „Człowiek człowiekowi wilkiem”.

Zakres materiału zawartego w książce i sposób jego prezentacji wskazuje na rozległą znajomość poruszanej problematyki oraz dużą erudycję. Umiejętnie odwołano się do raportów organizacji wyspecjalizowanych w monitorowaniu przestrzegania praw człowieka m.in.: Rady Praw Człowieka, Wysokiego Komisarza Narodów Zjednoczonych ds. Uchodźców, Wysokiego Komisarza Narodów Zjednoczonych ds. Praw Człowieka, Sekretarza Generalnego ONZ, Światowego Programu Żywnościowego, Światowej Organizacji Zdrowia, Amnesty International, Międzynarodowego Komitetu i Federacji Towarzystw Czerwonego Krzyża oraz organizacji Lekarze bez Granic.

Książka Ludzie w cieniu wojny jest interesującym studium politologiczno-prawnym, o którego wartości decyduje m.in. rzetelność i zwięzłość wywodu oraz dociekliwość Autorki. Jest to opracowanie o wyraźnie nakreślonym profilu naukowo-badawczym. Bardzo istotnym wzbogaceniem pracy jest też jej interdyscyplinarność, sprowadzająca się do ciekawego umiejscowienia podjętego problemu w szerszym kontekście: politycznym, kulturowym, społecznym, prawnym czy ekonomicznym. Rozszerza to znacznie spektrum potencjalnych czytelników. 